\title{
PENINGKATAN PENGETAHUAN IBU DALAM UPAYA PENCEGAHAN TUBERCULOSIS PADA ANAK DI WILAYAH KERJA PUSKESMAS SENTANI
}

\author{
Ellen R.V. Purba'), Frans Manangsang1), Ester Rumaseb"1), Elisabeth Gultom ${ }^{1)}$, \\ Nugroho Wicaksono"), Lea Sintia Tumei'), Wiwit Mawati Nainggolan'), Theresia Rahel Yokhu1) \\ 1)Jurusan Keperawatan, Politeknik Kesehatan Kemenkes Jayapura, Jayapura, Papua, Indonesia \\ Corresponding author: Ellen R.V. Purba \\ Email : ellen.purba5@gmail.com
}

Diterima 05 Juli 2021, Direvisi 27 Juli 2021, Disetujui 27 Juli 2021

\begin{abstract}
ABSTRAK
Penyakit Tuberculosis hingga saat ini masih menjadi perhatian dunia. Hal ini dikarenakan angka kematian akibat Tuberculosis masih tinggi, dimana angka tertinggi terjadi di negara berkembang. Memberikan pendidikan kesehatan mengenai pencegahan Tuberculosis kepada masyarakat atau kelompok dapat membentuk dan mempersiapkan masyarakat terhadap pencegahan primer penyakit tuberculosis. Kegiatan pengabdian kepada masyarakat ini mempunyai tujuan memberikan pemahaman Ibu sebagai PMO tentang upaya pencegahan Tuberculosis pada anak diwilayah kerja Puskesmas Sentani. Pelaksanaan kegiatan dilakukan pada dua tempat yaitu posyandu Dabonsolo dan Yahim dengan metode sosialisasi yaitu penyuluhan Tuberculosis, simulasi/demonstrasi cuci tangan pakai sabun serta memakai masker, dan role play Etika Batuk. Kegiatan diikuti oleh 49 orang yang berada di wilayah kerja Puskesmas Sentani dan dilakukan pengukuran pretest dan postest untuk mengetahui efektivitas kegiatan. Hasil pengukuran pengetahuan menujukan bahwa terjadinya peningkatan pengetahauan yang dimiliki oleh peserta tentang upaya pencegahan tuberculosis sebelum dan setelah kegiatan sosialisasi.
\end{abstract}

Kata kunci: Tuberculosis; peningkatan pengetahuan; anak.

\begin{abstract}
The disease tuberculosis there is still worldwide attention. This is the mortality rate is high, tuberculosis which the figures the highest were in developing countries. Provide education health on the prevention of tuberculosis to the people or groups can shape and prepare people for primary prevention of disease tuberculosis. This activity has the purpose of giving the mother as PMO about efforts to prevent tuberculosis in children in the work area Sentani community health centers. The implementation of community activities carried on two places are Dabonsolo and Yahim with the methods of socialization is counseling tuberculosis, the simulation/demonstration washing hands with soap and wearing a mask, and role play ethics cough. Activities followed by 49 people who are in the work area of Puskesmas Sentani and was conducted the measurement of pretest and postest to know the effectiveness of activities. The measurement result showing that knowledge will increase knowledge possessed by participants about efforts to prevent tuberculosis before and after socialization
\end{abstract}

Kata kunci: Tuberculosis; knowledge increased; children

\section{PENDAHULUAN}

Pengawas menelan obat adalah seseorang yang secara sukarela membantu pasien TB dalam masa pengobatan hingga sembuh. Oleh karena itu monitoring dalam pencegahan Tuberculosis ini dapat dilakukan diposyandu dengan cara mengoptimalkan peran aktif kader posyandu khususnya ibu yang mendampingi anak sebagai pengawas menelan obat. Tugas dari PMO adalah memberikan penyuluhan tentang Tuberculosis kepada keluarga pasien atau orang yang tinggal serumah, memastikan pasien menelan obat sesuai aturan sejak awal pengobatan sampai sembuh, mendampingi dan memberikan dukungan moral kepada pasien agar dapat menjalani pengobatan secara lengkap dan teratur (Febrina, 2018)

Tuberculosis merupakan suatu penyakit menular yang disebabkan oleh basil Mikrobacterium tubercolusis yang merupakan salah satu penyakit saluran pernafasan bagian bawah yang sebagian besar basil tuberkolusis masuk ke dalam jaringan paru melalui airbone infection dan selanjutnya mengalami proses yang dikenal sebagai fokus primer dari ghon (Potter, P. A., Perry, A.G., Stockert, P. A., \& Hall, 2005). Penyakit Tuberkulosis (Tuberculosis) hingga saat ini masih menjadi perhatian dunia. Hal ini dikarenakan angka kematian akibat Tuberculosis masih tinggi, 
dimana angka tertinggi terjadi di negara berkembang World Health Organization (World Health Organization International, 2012). Sepertiga dari populasi dunia sudah tertular dengan Tuberculosis dimana sebagian besar penderita Tuberculosis adalah usia produktif (15-55 tahun). Hal ini menyebabkan kesehatan yang buruk di antara jutaan orang setiap tahun dan menjadi penyebab utama kedua kematian dari penyakit menular diseluruh dunia, setelah Human Immunodeficiency Virus (HIV)/ AIDS (Acquired Immune Deficiency Syndrome).

Salah satu faktor penyebabnya adalah masih rendahnya kepatuhan dan ketaatan pasien Tuberculosis selama menjalani pengobatan standar.Penatalaksanaan Tuberculosis dengan program DOTS dapat memberikan kesembuhan bagi penderita Tuberculosis, apabila terdapat kepatuhan dari pasien dan melakukan pengobatan secara teratur. Lamanya pengobatan ini dapat mengakibatkan kejenuhan bagi pasien Tuberculosis, yang pada akhirnya mereka tidak mau lagi untuk mengkonsumsi obat sehingga dapat mengakibatkan pasien Tuberculosis tidak sembuh dan juga menjadi resisten terhadap Obat Anti Tuberkulosis (OAT). Ketidakpatuhan merupakan penyebab utama terjadinya kegagalan dalam pengobatan atau drop out dan meningkatkan terjadinya kasus Multi Drugs Resistant (MDR) (Rahmi, N., Medison, I., \& Suryadi, 2017).

World Health Organization, (2019) dalam Adherence to long-term therapies mengemukakan bahwa ketidak patuhan terhadap pengobatan juga dapat mengakibatkan peningkatan risiko morbiditas, mortalitas, dan ketahanan terhadap obat standar. Untuk mengantisipasi hal ini, maka perlu adanya pengawasan pada penderita Tuberculosis selama melakukan pengobatan dan pemberian informasi atau peningkatan pengetahuan dapat dilakukan melalui pendidikan kesehatan terkait upaya pencegahan Tuberculosis.

Pendidikan kesehatan pada hakikatnya adalah suatu kegiatan menyampaikan pesan kesehatan pada masyarakat, kelompok atau individu. Pendidikan kesehatan dilakukan dengan pemberian penyuluhan kesehatan atau informasi melalui berbagai media dan teknologi guna meningkatkan pengetahuan dan sikap positif terhadap kesehatan (Notoatmodjo, 2013). Menurut WHO, memberikan pendidikan kesehatan mengenai pencegahan Tuberculosis kepada masyarakat atau kelompok dapat membentuk dan mempersiapkan masyarakat terhadap pencegahan primer penyakit tuberculosis. Salah satu metode untuk memberikan pendidikan kesehatan adalah dengan menggunakan media yang baik serta sesuai dengan tujuan yang dicapai (World Health Organization, 2017).

Di Provinsi Papua sendiri diperoleh jumlah data penemuan kasus baru BTA positif sebanyak 2,050 kasus (Dinas Kesehatan Provinsi Papua, 2016). Angka kejadian Tuberculosis diwilayah Sentani pada tahun 2018 berjumlah 901 penderita di Kabupaten Jayapura. Berdasarkan hal tersebut tujuan dari kegiatan pengbdian kepada menyarakat ini adalah untuk memberikan pemahaman ibu sebagai PMO tentang upaya pencegahan tuberculosis pada anak diwilayah kerja Puskesmas Sentani.

\section{METODE}

Kegiatan pengabdian ini dilaksanakan di posyandu Dabonsolo dan Yahim yang dimana berada si Wilayah Kerja Puskesmas Sentani, Jayapura, Provinsi Papua. Kegiatan dilaksanakan pada tanggal 25 Maret sampai 20 Mei 2021. Sasaran kegiatan ini adalah keluarga/Orang Tua (ibu) sebagai pengawas minum obat pada anak. Jumlah keluarga/Orang Tua (ibu) yang mengikuti kegiatan ini adalah 49 orang dengan rincian posyandu Dabonsolo sebanyak 22 peserta dan posyandu Yahim sebanyak 27 peserta. Kegiatan ini dilakukan melalui pemberian sosialisasi kesehatan dengan metode ceramah, demonstrasi, role play, tanya jawab dan diskusi. Tahapan yang dilaksanakan dalam kegiatan ini meliputi:

1. Persiapan kegiatan: Koordinasi dengan Kepala Pusksmas Sentani serta Kader Posyandu untuk menetukan waktu yang tepat dalam memberikan penyuluhan kesehatan.

2. Memberikan Kuesioner Pretest kepada peserta

3. Menyampaikan materi penyuluhan kesehatan dengan metode ceramah tentang upaya pencegahan tuberculosis, simulasi/demontrasi mencuci tangan menggunakan sabun dan memakai masker pada peserta yang menjadi PMO, dan role play etika batuk kepad peserta.

4. Melakukan feedback (diskusi dan tanya jawab) terkait materi yang telah disampaikan.

5. Memberikan kuesioner posttest kepada peserta sebagai bentuk evaluasi kegiatan.

\section{HASIL DAN PEMBAHASAN Hasil}

Pelaksanaan Pengabdian masyarakat yang pertama dilaksanakan pada hari kamis tanggal 25 Maret 2021 yang bertempat di Posyandu Dabonsolo Wilayah Kerja Puskesmas Sentani. Kegiatan yang 
bertemakan "Peningkatan Pengetahuan Ibu Dalam Upaya Pencegahan Tuberculosis Pada Anak di Wilayah Kerja Puskesmas Sentani" di hadiri oleh 22 peserta yang merupakan orang tua dari anak-anak diwilayah Kerja Puskesmas Sentani seperti yang terlihat pada Gambar 1 berikut:

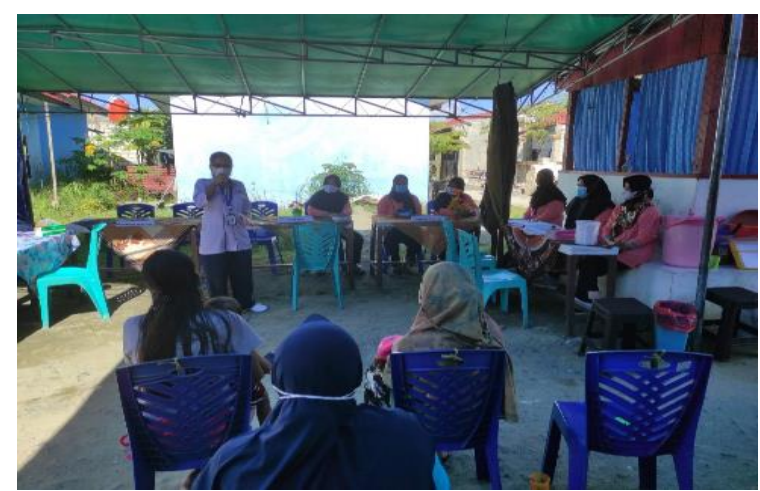

Gambar 1. Sosialisasi di Posyandu Dabonsolo

Acara di awali dengan sambutan dan penjalasan kegiatan kepada semua peserta dan dilanjutkan dengan pengukuran pengetahuan peserta tentang upaya pencegahan tuberculosis sebelum di berikannya materi sosialisasi tentang upaya pencegahan Tuberculosis, Simulasi/Demonstrasi pada orang tua/lbu menjadi PMO untuk mencegah Tuberculosis dengan melakukan Cuci tangan pakai sabun, Role play Etika Batuk, dan Simulasi Memakai Masker. Kegiatan diakhiri dengan diskusi dan pengukuran kembali pengetahuan peserta tentang upaya pencegahan tuberculosis. Berdasarkan hasil pengukuran upaya pencegahan tuberculosis sebelum dan setelah diberikannya sosialisasi di dapatkan bahwa terjadinya peningkatan pengetahauan yang dimiliki oleh peserta tentang upaya pencegahan tuberculosis yang di sajikan dalam bentuk grafik dibawah ini :

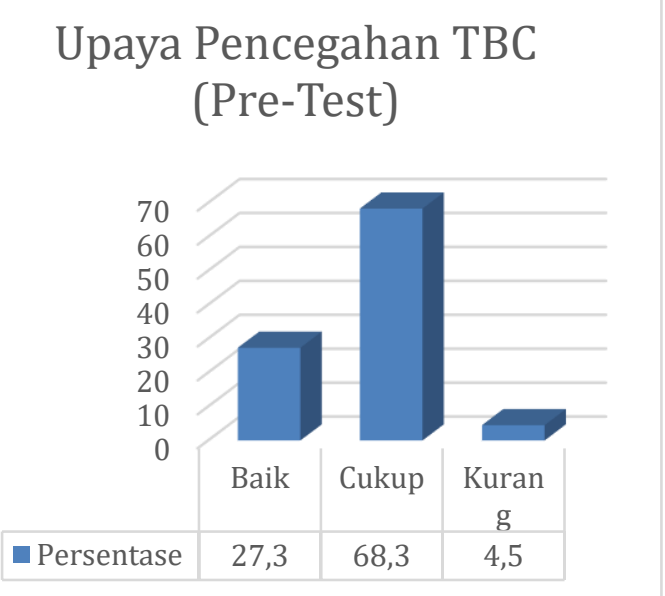

Gambar 2. Hasil Pre test di Posyandu Dabonsolo
Gambar 2 menunjukan hasil pretest kuesioner tentang upaya pencegahan tuberkulosis di Posyandu Dabonsolo yaitu sebagian besar responden memiliki pengetahuan yang cukup sebanyak 15 responden $(68,2 \%), 1$ responden $(4,5 \%)$ mempunyai pengetahuan dalam kategori kurang dan 6 responden $(27,3 \%)$ memiliki pengetahuan dalam kategori baik tentang upaya pencegahan tuberculosis.



Gambar 3. Hasil Post test di Posyandu Dabonsolo

Gambar 3 menunjukan hasil pretest kuesioner tentang upaya pencegahan tuberkulosis di Posyandu Dabonsolo yaitu sebagian besar responden memiliki pengetahuan yang baik sebanyak 12 responden $(54,5 \%)$ sedangkan 10 responden $(45,5 \%)$ lainnya mempunyai pengetahuan dalam kategori cukup tentang upaya pencegahan tuberkulosis setelah diberikannya pendidikan kesehatan.

Pelaksanaan Pengabdian masyarakat yang kedua dilaksanakan pada hari kamis tanggal 22 April 2021 yang bertempat di Posyandu Yahim Wilayah Kerja Puskesmas Sentani. Kegiatan yang bertemakan "Peningkatan Pengetahuan Ibu Dalam Upaya Pencegahan Tuberculosis Pada Anak di Wilayah Kerja Puskesmas Sentani" di hadiri oleh 27 peserta yang merupakan orang tua dari anak-anak diwilayah Kerja Puskesmas Sentani seperti yang terlihat pada Gambar 4 berikut: 


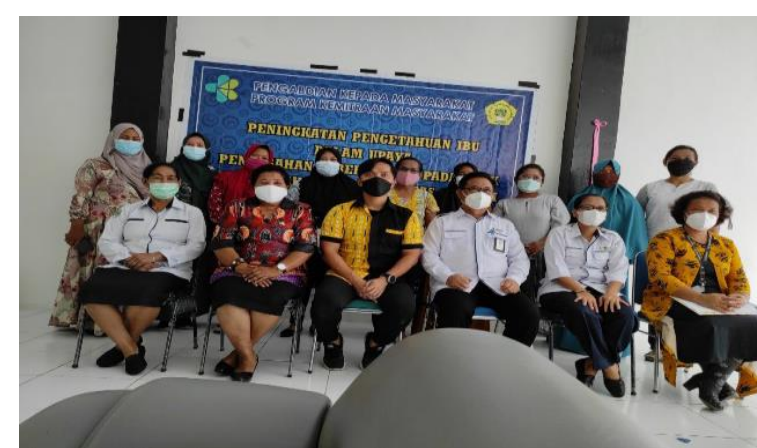

Gambar 4. Sosialisasi di Posyandu Yahim

Acara di awali dengan sambutan dan penjalasan kegiatan kepada semua peserta dan dilanjutkan dengan pengukuran pengetahuan peserta tentang upaya pencegahan tuberculosis sebelum di berikannya materi sosialisasi tentang upaya pencegahan Tuberculosis, Simulasi/Demonstrasi pada orang tua/lbu menjadi PMO untuk mencegah Tuberculosis dengan melakukan Cuci tangan pakai sabun, Role play Etika Batuk, dan Simulasi Memakai Masker. Kegiatan diakhiri dengan diskusi dan pengukuran kembali pengetahuan peserta tentang upaya pencegahan tuberculosis. Berdasarkan hasil pengukuran upaya pencegahan tuberculosis sebelum dan setelah diberikannya sosialisasi di dapatkan bahwa terjadinya peningkatan pengetahauan yang dimiliki oleh peserta tentang upaya pencegahan tuberculosis yang di sajikan dalam bentuk grafik pada gambar Gambar 5 dibawah ini :



Gambar 5. Hasil Pre test di Posyandu Yahim

Gambar 5 menunjukan hasil pretest kuesioner tentang upaya pencegahan tuberkulosis di Posyandu Yahim yaitu sebagian besar responden memiliki pengetahuan yang cukup sebanyak 19 responden $(70,4 \%), 4$ responden $(14,8 \%)$ mempunyai pengetahuan dalam kategori kurang dan 4 responden $(14,8 \%)$ memiliki pengetahuan dalam kategori baik tentang upaya pencegahan tuberkulosis.



Gambar 6. Hasil Post test di Posyandu Yahim

Gambar 6 menunjukan hasil post test kuesioner tentang upaya pencegahan tuberkulosis di Posyandu Yahim yaitu sebagian besar responden memiliki pengetahuan yang baik sebanyak 18 responden $(66,7 \%)$ sedangkan 9 responden $(33,3 \%)$ lainnya mempunyai pengetahuan dalam kategori cukup tentang upaya pencegahan tuberkulosis setelah diberikannya pendidikan kesehatan.

\section{Pembahasan}

Kegiatan penyuluhan diawali dengan koordinasi dengan pihak Puskesmas Sentani dan Kader Poyandu Dabonsolo dan Yahim untuk mendiskusikan rincian acara yang akan dilaksanakan. kegiatan berlangsung di dua tempat yaitu di Posyandu Dabonsolo dan Posyandu Yahim. Kegiatan selanjutnya dilakukan dengan penjelasan tujuan kegiatan kepada peserta serta pembagian kuesioner pre-tets tentang pengetahuan upaya pencegahan Tuberculosis. Upaya pencegahan Tuberculosis dalam kuesioner tersebut berisikan tindakan yang pernah dilakukan peserta dalam mencegah penyakit Tuberculosis sehigga dapat menurunkan angka kematian yang disebabkan oleh penyakit tuberculosis. Kegiatan selanjutnya yaitu Menyampaikan materi penyuluhan kesehatan dengan metode ceramah tentang upaya pencegahan tuberculosis, simulasi/demontrasi mencuci tangan menggunakan sabun dan memakai masker pada peserta yang menjadi $\mathrm{PMO}$, serta role play etika batuk kepada peserta.

Pre-tets dan post-tets sebagai bahan evaluasi dilakukan dengan metode selfassesment, peserta menjawab sendiri kuesioner dengan bantuan instruktur dari kader dan panitia. Hasil Pre-tets dan post-tets 
menunjukan bahwa terjadi peningkatan pengetahuan peserta dari sebelum diberikan penyuluhan dan setelah diberikan penyuluhan kesehatan tentang Tuberculosis yang di jelaskan pada Gambar 2 dan 3 di Posyandu Dabonsolo. Hasil tersebut menujukan bahwa sebelum diberikannya penyuluhan kesehatan tentang Tuberculosis menunjukan sebagian besar pengetahuan peserta dalam kategori yang cukup sebanyak 15 responden $(68,2 \%), 1$ responden $(4,5 \%)$ mempunyai pengetahuan dalam kategori kurang dan 6 responden $(27,3 \%)$ memiliki pengetahuan dalam kategori baik tentang upaya pencegahan tuberkulosis, sedangkan setelah diberikannya penyuluhan kesehatan menujukan bahwa sebagian besar responden memiliki pengetahuan yang baik sebanyak 12 responden $(54,5 \%)$ sedangkan 10 responden $(45,5 \%)$ lainnya mempunyai pengetahuan dalam kategori cukup tentang upaya pencegahan tuberkulosis setelah diberikannya pendidikan kesehatan. Hasil pengukuran Pre-tets dan post-tets di Posyandu Yahim juga menunjukan bahwa terjadi peningkatan pengetahuan peserta dari sebelum diberikan penyuluhan dan setelah diberikan penyuluhan kesehatan tentang Tuberculosis yang di jelaskan pada Gambar 5 dan 6 . Hasil tersebut menunjukkan bahwa sebelum diberikannya penyuluhan kesehatan sebagian besar responden memiliki pengetahuan yang cukup yaitu sebanyak 19 responden $(70,4 \%), 4$ responden $(14,8 \%)$ mempunyai pengetahuan dalam kategori kurang dan 4 responden $(14,8 \%)$ memiliki pengetahuan dalam kategori baik tentang upaya pencegahan tuberkulosis. Setelah di berikannya penyuluhan kesehatan menunjukan bawa sebagian besar responden memiliki pengetahuan yang baik sebanyak 18 responden $(66,7 \%)$ sedangkan 9 responden $(33,3 \%)$ lainnya mempunyai pengetahuan dalam kategori cukup tentang upaya pencegahan tuberkulosis. Upaya pencegahan penyakit Tuberculosi dilakukan untuk menurunkan angka kematian yang disebabkan oleh penyakit Tuberculosis.

Dukungan dari keluarga yang baik dan positif dengan berpartisifasi penuh dalam pengobatan Tuberculosis akan mengurangi angka kematian yang terjadi (Pangestika et al., 2019). Pemberdayaan keluarga dapat meningkatkan self efficacy (keyakinan diri) dan self care activity (perawatan diri) keluarga dan penderita Tuberculosis dalam perawatan keluarga yang sakit di rumah (Muhtar, 2013). Semakin tinggi self efficacy seseorang berdampak pada peningkatan self care activity orang tersebut (Muhtar, 2013). Hal tersebut menjelaskan bahwa, penyuluhan melalui pemberdayaan anggota keluarga sangat diperlukan dalam upaya preventif pencegahan penyakit menular Tuberculosis (Getahun et al., 2012).

\section{SIMPULAN DAN SARAN}

Hasil kegiatan pengabdian masyarakat yang telah dilakukan dapat di simpulkan bahwa terjadi peningkatan pengetahuan peserta tentang upaya pencegahan Tuberculosis di wilayah kerja Puskesmas Sentani. penyuluhan melalui pemberdayaan anggota keluarga sangat diperlukan dalam upaya preventif pencegahan penyakit menular Tuberculosis di tingkat keluarga. Diharapkan pihak Puskesmas, Kader posyandu dan Instansi terkait dapat melakukan kerja sama lanjutan seperti membentuk kelompok khusus sebagai wadah koordinasi dan berbagi informasi dalam upaya meningkatakan pengetahuan masyarakat dan dapat meningkatkan derajat kesehatan.

\section{UCAPAN TERIMAKASIH}

Penulis menyampaikan terimakasih kepada semua pihak yang telah membantu dalam pelaksanaan kegiatan pengabdian masyarakat ini. Secara khusus penulis ingin berterimakasih kepada Politeknik Kesehatan Kemenkes Jayapura yang telah memberikan bantuan pendanaan sehingga kegiatan dapat terlaksana dengan baik.

\section{DAFTAR RUJUKAN}

Febrina, W. (2018). Analisis Peran Keluarga sebagai Pengawas Minum Obat (PMO) Pasien TB Paru. Human Care Journal, 3(2), 118-129. https://doi.org/http://dx.doi.org/10.32883/ hcj.v3i2.66

Getahun, H., Sculier, D., Sismanidis, C., Grzemska, M., \& Raviglione, M. (2012). Prevention, diagnosis, and treatment of tuberculosis in children and mothers: Evidence for action for maternal, neonatal, and child health services. Journal of Infectious Diseases, 205(SUPPL. 2). https://doi.org/10.1093/infdis/jis009

Muhtar. (2013). Pemberdayaan Keluarga Dalam Peningkatan Self Efficacy Dan Self Care Activity Keluarga Dan Penderita Tb Paru (Family Empowerment in Increasing Self-Effi cacy and Self-Care Activity of Family and Patients with Pulmonary $\mathrm{Tb}$ ). Jurnal Ners, 8(2), 229-239. https://doi.org/http://dx.doi.org/10.20473/j n.v8i2.3826

Notoatmodjo. (2013). Promosi dan Perilaku Kesehatan. Renika Cipta.

Pangestika, R., Fadli, R. K., \& Alnur, R. D. (2019). Edukasi Pencegahan Penularan Penyakit Tb melalui Kontak Serumah. 
Jurnal SOLMA, 8(2), 229. https://doi.org/10.29405/solma.v8i2.3258

Potter, P. A., Perry, A.G., Stockert, P. A., \& Hall, A. (2005). Fundamental of Nursing: Fundamental Keperawatan. Selemba Medika.

Rahmi, N., Medison, I., \& Suryadi, I. (2017). Hubungan Tingkat Kepatuhan Penderita Tuberkulosis Paru dengan Perilaku Kesehatan, Efek Samping OAT dan Peran PMO pada Pengobatan Fase Intensif di Puskesmas Seberang Padang September 2012-Januari 2013. Jurnal Kesehatan Andalas, 6(2), 345-350. https://doi.org/https://doi.org/10.25077/jka .v6i2.702

World Health Organization. (2017). Health Education. Retrieved November 30, 2017. http://www.who.int/topics/health_educatio n/en/

World Health Organization. (2019). Adherence To Long Term Therapies Evid Ence For Action Retrieved 30 Januari, 2019. http://apps.who.int/iris/bitstream/10665/4 2682/1/9241545992.pdf

World Health Organization International. (2012). Global Tubercolosis Report 2012. http://www.who.int/tb/publications/global_ report/en/ 